\title{
Aquifer Vulnerability Investigation Using Geoelectric Method in Parts of Sapele Local Government Area of Delta State, Nigeria
}

\author{
E. A. Atakpo \\ Department of Physics, Delta State University, Abraka, Nigeria \\ [Corresponding author, e-mail: eatakpo@yahoo.com, atakpo@deltastate.edu.ng; 留: +234(0)8063864178]
}

\begin{abstract}
The electrical resistivity survey has been used in the determination of the overburden protective capacity in Amukpe area of Delta State, Nigeria. Nineteen Schlumberger vertical electrical soundings (VES) were carried out with maximum electrode separation of $1000 \mathrm{~m}$. The data were presented as VES curves interpreted quantitatively by computer iteration using the Resist Software to obtain the first order geoelectric parameters. Three geoelectric layers namely the topsoil, laterite/clayey sand and sand (medium to coarse grained) were delineated from the survey. The topsoil has resistivity values ranging from 43 to $1067 \Omega m$ and thickness varying from 0.8 to $1.6 \mathrm{~m}$. The second geoelectric layer is composed of clayey sand and laterite with resistivity values ranging from 77 to $644 \Omega \mathrm{m}$ and thickness varying from 3.8 to $6.7 \mathrm{~m}$. While the third geoelectric layer represents the aquiferous unit with resistivity values ranging from 200 to $1067 \Omega \mathrm{m}$ diagnostic of sand (fine to coarse grained). The interpreted geoelectric data correlated with lithologic logs of a borehole drilled in the study area. The overburden protective capacity in an area was evaluated by utilizing the total longitudinal unit conductance values. The generated longitudinal conductance map showed poor protective capacity $(<0.1 \mathrm{mhos})$ in all parts of the study area. The low value of the protective capacity makes the aquifer in the study area vulnerable to contamination especially hydrocarbon in the event of pollution.

Keywords: Protective capacity, Amukpe, Geoelectric, Pollution.
\end{abstract}

\section{INTRODUCTION}

Sapele Local government area of Delta State, Nigeria comprise several oil producing communities such as Amukpe, Adagbrasa, etc, that play host to oil fields, flow station and extensive network of pipe lines within the fields as well as small networks of flow lines.

These oil and gas related installations allow many opportunities for oil leaks and spills in the area which may occur due to a variety of reasons such as blowouts resulting from overpressure, equipment failure, operators errors, corrosion, vandalisation of pipelines, pigging operations, flow line replacement, flow station upgrades, tank rehabilitation and natural phenomena such as heavy rainfall, flooding, falling of trees, lightening and poor management practices around oil installation (Ozumba et al., 1999; Atakpo and Ayolabi, 2008). When spills occur it leads to underground leakages which impact the environment in the form of groundwater pollution, soil pollution and destruction of vegetation. This may have a more direct impact on man if the subsurface pollution is not noticed on the surface but percolates to the aquifer which is an important source of potable water (Atakpo and Ayolabi, 2008). In the study area, depth to water is less than 1 meter in the wet season and at a maximum of 5 meters below the ground surface in the dry season (Akpoborie et al., 2000; McGill Engineering, 2005) making the area highly susceptible to pollution when ever spill occurs.

Apart from a few boreholes providing potable water, the communities rely mostly on water from dug wells for domestic and agricultural purposes. However, there is an increased demand for portable water in the study area as a result of urbanization and industrialization to cater for industrial, agricultural and domestic needs. An evaluation of the aquifer protective capacity is very important in such oil producing communities to ascertain the portability of the water.

Thus, the main objectives of the study is to carry out detailed geological and hydrogeological mapping of Amukpe area, conduct geophysical study to determine the geoelectric parameters (resistivity, $\rho_{i}$ and thickness, $h_{i}$ ) and delineate the depth to the aquifer and its lateral extent and determine the aquifer protective capacity. Henriet (1976) showed that the combination of layer resistivity and thickness in the Dar Zarrouk parameters $S$ (longitudinal conductance) and $\mathrm{T}$ (transverse resistance) may be of direct use in aquifer protection studies and for the evaluation of hydrologic properties of aquifer. The protective capacity is considered to be 
proportional to the longitudinal unit conductance in mhos (Olorunfemi et al., 1998; Oladapo et al., 2004; Ayolabi, 2005 and Atakpo and Ayolabi, 2008).

\section{Location and Geology of Survey Area}

The study area, Amukpe is area located within Longitude $05^{\circ} 44^{\prime} 30^{\prime \prime} \mathrm{E}$ to $05^{\circ} 44^{\prime} 43^{\prime \prime} \mathrm{E}$ and Latitude $05^{\circ} 51^{\prime} 55^{\prime \prime} \mathrm{N}$ to $05^{\circ} 52^{\prime} 03^{\prime \prime} \mathrm{N}$ (Figure 1) in Sapele Local Government Area of Delta State, Nigeria. The study area displays the characteristic features of seaward sloping flat and featureless Sombreiro Warri Deltaic plain (Short and Stauble, 1967).

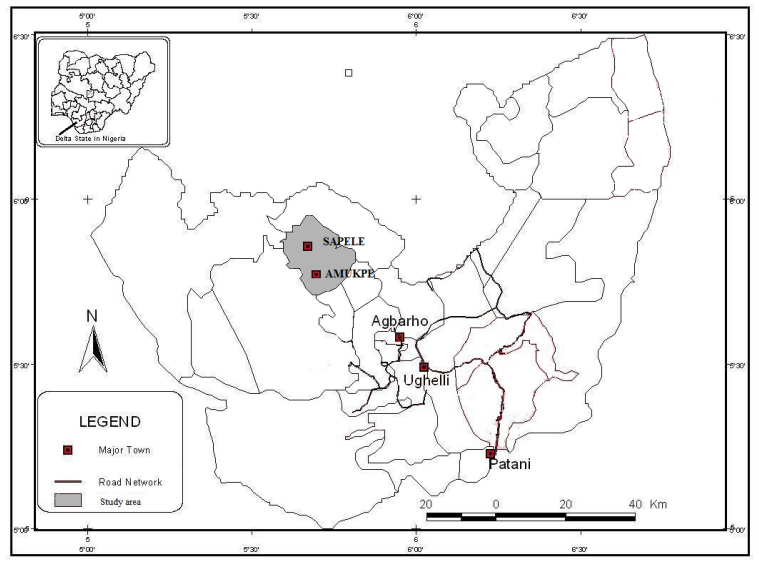

Figure 1: Location map of study area

Elevation is about $10 \mathrm{~m}$ above sea level. Fresh water swamps occupy the low lying depressions as well as the riverbanks. The vegetation is typical of the rain forest except along drainage streams where swampy areas exist. The Niger Delta Petroleum provinces much studied and is underlain by three main stratigraphic units (Short and Stauble, 1967; Asseez, 1989). These are the basal Akata Formation of mainly marine shale and sand beds. This is overlain by the paralic sequence consisting of interbedded sands and shales of the Agbada Formation. The youngest Benin Formation is a prolific aquifer and is penetrated everywhere in the modern Niger Delta by numerous water supply boreholes. However, the formation is masked in the Sombreiro - Deltaic plain by a sequence of silts, medium to coarse grained sands, sandy clays and clay bands which Oomkens (1974) believes are a result of interglacial marine transgressions that have occurred in the Quaternary. This sequence is indistinguishable from the underlying Benin Formation in borehole sections and is indeed the present day expression of this formation. The problem though is that the clay bands are not uniform in thickness and many boreholes have been abandoned because the entire clay sequence could not be penetrated in order to access the underlying water bearing sandy layers or the aquifer.

\section{Theory}

The generalized form of electrode configuration in resistivity survey is shown in Figure 2.

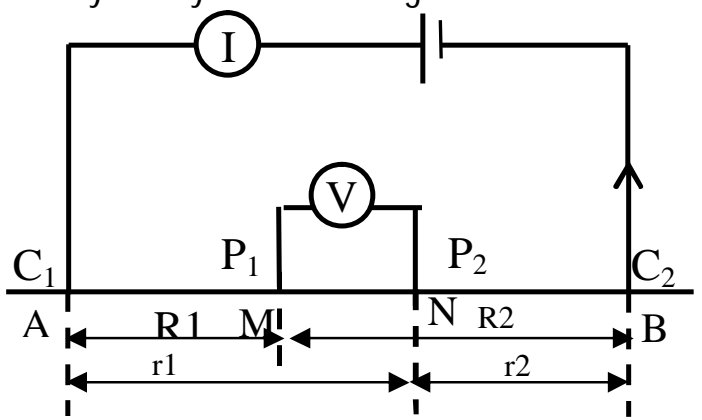

Figure 2: Generalized form of Electrode Configuration

The potential at the electrode $\mathrm{M}$ and $\mathrm{N}$ are,

$$
\begin{aligned}
& \mathrm{V}_{\mathrm{M}}=\frac{\rho_{\mathrm{a}} \mathrm{I}}{2 \pi}\left(\frac{1}{\mathrm{R} 1}-\frac{1}{\mathrm{R} 2}\right) \\
& \mathrm{V}_{\mathrm{N}}=\frac{\rho_{\mathrm{a}} \mathrm{I}}{2 \pi}\left(\frac{1}{\mathrm{r} 1}-\frac{1}{\mathrm{r} 2}\right)
\end{aligned}
$$

However the measured parameter is the difference in potential between $\mathrm{M}$ and $\mathrm{N}$, from equations 1 and 2 ,

$$
\Delta \mathrm{V}_{\mathrm{MN}}=\frac{\rho_{\mathrm{a}} \mathrm{I}}{2 \pi}\left[\left(\frac{1}{\mathrm{R} 1}-\frac{1}{\mathrm{R} 2}\right)-\left(\frac{1}{\mathrm{r} 1}-\frac{1}{\mathrm{r} 2}\right)\right]----(3)
$$

Hence

$\rho_{\mathrm{a}}=\frac{2 \pi \Delta \mathrm{V}_{\mathrm{MN}}}{\mathrm{I}}\left[\left(\frac{1}{\mathrm{R} 1}-\frac{1}{\mathrm{R} 2}\right)-\left(\frac{1}{\mathrm{r} 1}-\frac{1}{\mathrm{r} 2}\right)\right]^{-1}=\mathrm{KR}_{\mathrm{es}}-(4)$

Where $\mathrm{K}=2 \pi\left[\frac{1}{\mathrm{R} 1}-\frac{1}{\mathrm{R} 2}-\frac{1}{\mathrm{r} 1}+\frac{1}{\mathrm{r} 2}\right]^{-1}$ and $R_{e s}=\frac{\Delta V_{M N}}{I}$

For the Schlumberger array used in this survey $\mathrm{MN}=\mathrm{b}$ and the distance from the current electrode on either side to the center of the potential electrode is given as ' $a$ ' where $a \geq 5 b$, thus,

$$
\begin{gathered}
K=\frac{\pi a^{2}}{b}\left[1-\frac{b^{2}}{4 a^{2}}\right] \quad \text { and } \\
\rho_{a}=\frac{\pi a^{2}}{b}\left[1-\frac{b^{2}}{4 a^{2}}\right] R_{e s}--------5
\end{gathered}
$$


$\mathrm{K}$ is the geometric factor obtained from the field configuration and $\rho_{a}$ is the apparent resistivity obtained from the field resistivity data (Ayolabi et al., 2009)

\section{METHODOLOGY}

The vertical electrical sounding (VES) involving the Schlumberger electrode array was used. A total of 19 Soundings stations were carried out. The VES stations are shown in Figure 3. The ABEM SAS 1000 portable Terrameter with an inbuilt booster for greater depth was used for the data acquisition. The maximum current electrode separation $(A B)$ was $1000 \mathrm{~m}$. The data obtained from the electrical resistivity survey was interpreted quantitatively by computer iteration with the aid of the Win Resist Software based on the work of Vander Velpen, (2004) to obtain the true resistivity and thickness of the layers delineated (Table 1).
These first order geoelectric parameters (resistivity $\rho_{i}$ and thickness $h_{i}$ ) were utilised in deriving the total Longitudinal unit conductance (S), which is a second order geoelectric parameter or the Dar Zarrouk Parameter (Maillet, 1947). The total longitudinal unit conductance is

$$
S=\sum_{i=1}^{n} \frac{h_{i}}{\rho_{i}}--------6
$$

Hence the overburden protective capacity was evaluated using the total longitudinal unit conductance values in the equation (Henriet, 1976, Oladapo et al, 2004, Atakpo and Ayolabi, 2008). The longitudinal conductance (mhos)/protective capacity ratings modified by Oladapo et al., (2004) as: >10 - Excellent; 5 to 10 - Very Good; 0.7 to 4.9 - good; $0.2-0.69$ moderate; 0.1 to 0.19 Weak and $<0.1$ - Poor were used for the interpretation of the protective capacity.

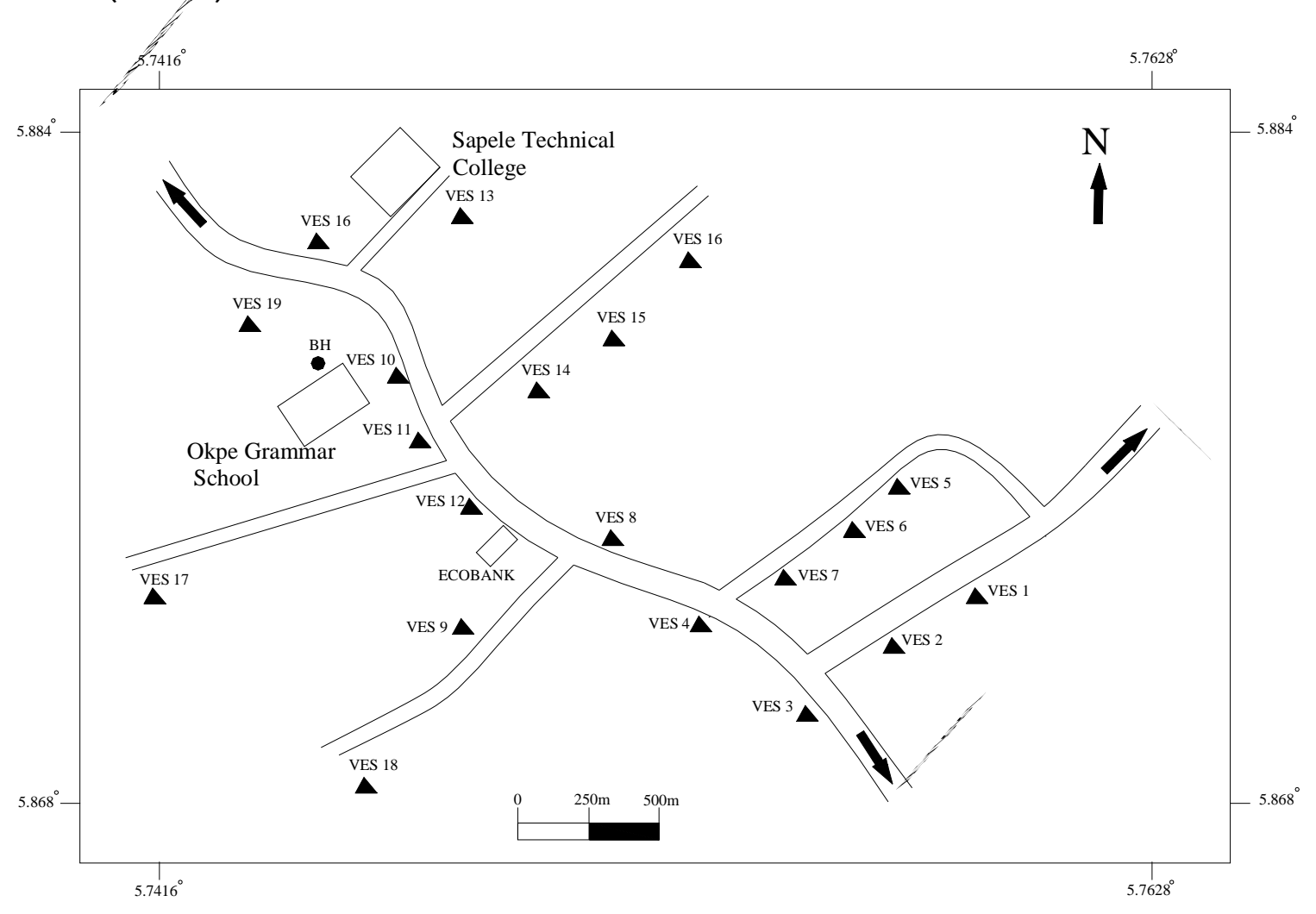

Figure 3: Data acquisition map of study area. 
Atakpo: Aquifer Vulnerability Investigation Using Geoelectric Method in Parts of Sapele Local Government Area ....

Table 1: Geoelectric parameters and lithologic delineation of study area.

\begin{tabular}{|c|c|c|c|c|c|c|}
\hline VES & Layer & Resistivity & Thickness & Lithology & $\mathrm{S}=\sum_{i=1}^{n} \frac{h_{i}}{\rho_{i}}$ & $\begin{array}{l}\text { Longitudinal conductivity } \\
\text { of protecting layers }\end{array}$ \\
\hline \multirow{5}{*}{ VES1 } & 1 & 113 & 1.5 & Topsoil & 0.013274 & 0.027683 \\
\hline & 2 & 465 & 6.7 & Laterite & 0.014409 & \\
\hline & 3 & 200 & 10.2 & Sand & 0.051 & \\
\hline & 4 & 394 & 8.7 & Sand & 0.022081 & \\
\hline & & 907 & - & Sand & & \\
\hline \multirow{4}{*}{ VES2 } & 1 & 43 & 1.4 & Topsoil & 0.032558 & 0.064204 \\
\hline & 2 & 237 & 7.5 & Laterite & 0.031646 & \\
\hline & 3 & 457 & 44.8 & Sand & 0.098031 & \\
\hline & 4 & 1063 & - & Sand & & \\
\hline \multirow{5}{*}{ VES3 } & 1 & 48.9 & 0.9 & Topsoil & 0.018405 & 0.09243 \\
\hline & 2 & 76.7 & 5.7 & Clayey sand & 0.074025 & \\
\hline & 3 & 1008 & 28.2 & Sand & 0.027976 & \\
\hline & 4 & 599 & 9.7 & Sand & 0.016194 & \\
\hline & 5 & 947 & - & Sand & & \\
\hline \multirow{4}{*}{ VES4 } & 1 & 363 & 0.9 & Topsoil & 0.002479 & 0.01572 \\
\hline & 2 & 506 & 6.7 & Laterite & 0.013241 & \\
\hline & 3 & 442 & 4.8 & Sand & 0.01086 & \\
\hline & 4 & 985 & - & Sand & & \\
\hline \multirow{4}{*}{ VES5 } & 1 & 121 & 1.1 & Topsoil & 0.009091 & 0.029621 \\
\hline & 2 & 302 & 6.2 & sand & 0.02053 & \\
\hline & 3 & 446 & 60 & Sand & 0.134529 & \\
\hline & 4 & 1022 & - & Sand & & \\
\hline \multirow{4}{*}{ VES6 } & 1 & 135 & 1.6 & Topsoil & 0.011852 & 0.024315 \\
\hline & 2 & 337 & 4.2 & Laterite & 0.012463 & \\
\hline & 3 & 309 & 44 & Sand & 0.142395 & \\
\hline & 4 & 869 & - & Sand & & \\
\hline \multirow{4}{*}{ VES7 } & 1 & 139 & 1.5 & Topsoil & 0.010791 & 0.041094 \\
\hline & 2 & 231 & 7.0 & Lateritic clay & 0.030303 & \\
\hline & 3 & 390 & 50 & Sand & 0.128205 & \\
\hline & 4 & 1041 & - & Sand & & \\
\hline \multirow{4}{*}{ VES8 } & 1 & 284 & 1.6 & Topsoil & 0.005634 & 0.014117 \\
\hline & 2 & 613 & 5.2 & Laterite & 0.008483 & \\
\hline & 3 & 434 & 38 & Sand & 0.087558 & \\
\hline & 4 & 894 & - & Sand & & \\
\hline \multirow{4}{*}{ VES 9} & 1 & 28 & 0.8 & Topsoil & 0.028571 & 0.03587 \\
\hline & 2 & 644 & 4.7 & Laterite & 0.007298 & \\
\hline & 3 & 495 & 52.1 & Sand & 0.105253 & \\
\hline & 4 & 325 & - & Sand & & \\
\hline \multirow{4}{*}{ VES 10} & 1 & 50 & 1.4 & Topsoil & 0.028 & 0.060766 \\
\hline & 2 & 235 & 7.7 & Laterite & 0.032766 & \\
\hline & 3 & 442 & 41 & Sand & 0.09276 & \\
\hline & 4 & 1037 & - & Sand & & \\
\hline \multirow{4}{*}{ VES 11} & 1 & 172 & 1.5 & Topsoil & 0.008721 & 0.018721 \\
\hline & 2 & 420 & 4.2 & Laterite & 0.01 & \\
\hline & 3 & 772 & 22 & Sand & 0.028497 & \\
\hline & 4 & 350 & 28 & Sand & 0.08 & \\
\hline
\end{tabular}


Nigerian Journal of Basic and Applied Science (March, 2013), 21(1): 11-19

Table 1 continues

\begin{tabular}{|c|c|c|c|c|c|c|}
\hline VES & Layer & Resistivity & Thickness & Lithology & $\mathrm{S}=\sum_{i=1}^{n} \frac{h_{i}}{\rho_{i}}$ & $\begin{array}{l}\text { Longitudinal conductivity } \\
\text { of protecting layers }\end{array}$ \\
\hline & 5 & 502 & - & Sand & & \\
\hline \multirow{5}{*}{ VES 12} & 1 & 755 & 1.1 & Topsoil & 0.001457 & 49.00146 \\
\hline & 2 & 251 & 4.1 & Laterite & 0.016335 & \\
\hline & 3 & 535 & 28.6 & Sand & 0.053458 & \\
\hline & 4 & 892 & 32.1 & Sand & 0.035987 & \\
\hline & 5 & 482 & - & Sand & & \\
\hline \multirow{5}{*}{ VES 13} & 1 & 234 & 1.2 & Topsoil & 0.005128 & 0.014637 \\
\hline & 2 & 631 & 6 & Laterite & 0.009509 & \\
\hline & 3 & 425 & 34 & Sand & 0.08 & \\
\hline & 4 & 809 & 46 & Sand & 0.05686 & \\
\hline & 5 & 378 & - & Sand & & \\
\hline \multirow{4}{*}{ VES 14} & 1 & 175 & 1.0 & Topsoil & 0.005714 & 0.014923 \\
\hline & 2 & 619 & 5.7 & Laterite & 0.009208 & \\
\hline & 3 & 782 & 54 & Sand & 0.069054 & \\
\hline & 4 & 392 & - & Sand & & \\
\hline \multirow{4}{*}{ VES 15} & 1 & 1067 & 1.0 & Topsoil & 0.000937 & 0.009214 \\
\hline & 2 & 592 & 4.9 & Laterite & 0.008277 & \\
\hline & 3 & 429 & 42.3 & Sand & 0.098601 & \\
\hline & 4 & 636 & - & Sand & & \\
\hline \multirow{5}{*}{ VES 16} & 1 & 163 & 1.2 & Topsoil & 0.00736 & 0.01547 \\
\hline & 2 & 530 & 4.3 & Laterite & 0.00811 & \\
\hline & 3 & 655 & 20 & Sand & 0.0305 & \\
\hline & 4 & 401 & 31 & Sand & 0.077 & \\
\hline & 5 & 585 & - & Sand & & \\
\hline \multirow{5}{*}{ VES 17} & 1 & 641 & 1.3 & Topsoil & 0.0020 & 0.0128 \\
\hline & 2 & 351 & 3.8 & Laterite & 0.0108 & \\
\hline & 3 & 631 & 19.6 & Sand & 0.0311 & \\
\hline & 4 & 982 & 35.3 & Sand & 0.0359 & \\
\hline & 5 & 678 & - & Sand & & \\
\hline \multirow{5}{*}{ VES 18} & 1 & 409 & 0.9 & Topsoil & 0.0022 & 0.01119 \\
\hline & 2 & 567 & 5.1 & Laterite & 0.00899 & \\
\hline & 3 & 934 & 27.3 & Sand & 0.029 & \\
\hline & 4 & 589 & 13.7 & Sand & 0.0232 & \\
\hline & 5 & 947 & - & Sand & & \\
\hline \multirow{4}{*}{ VES 19} & 1 & 381 & 1.4 & Topsoil & 0.0036 & 0.0130 \\
\hline & 2 & 524 & 4.9 & Laterite & 0.0094 & \\
\hline & 3 & 641 & 32 & Sand & 0.0499 & \\
\hline & 4 & 994 & - & Sand & & \\
\hline
\end{tabular}




\section{RESULTS AND DISCUSSION}

The results of this study are presented as sounding curves, geoelectric sections and a protective capacity map. The electrical resistivity curves obtained range from four to five layers $A A$, $\mathrm{KQ}, \mathrm{KH}, \mathrm{KHA}, \mathrm{AKH}$ type curves (Figure 4). Two geoelectric sections were drawn using the first order geoelectric parameters (Figure 5 and 6) while a protective capacity map of the area was generated from the longitudinal conductance values with the aid of SURFER 8 (2002) Terrain and 3D Surface modeling software as shown in Figure 7.
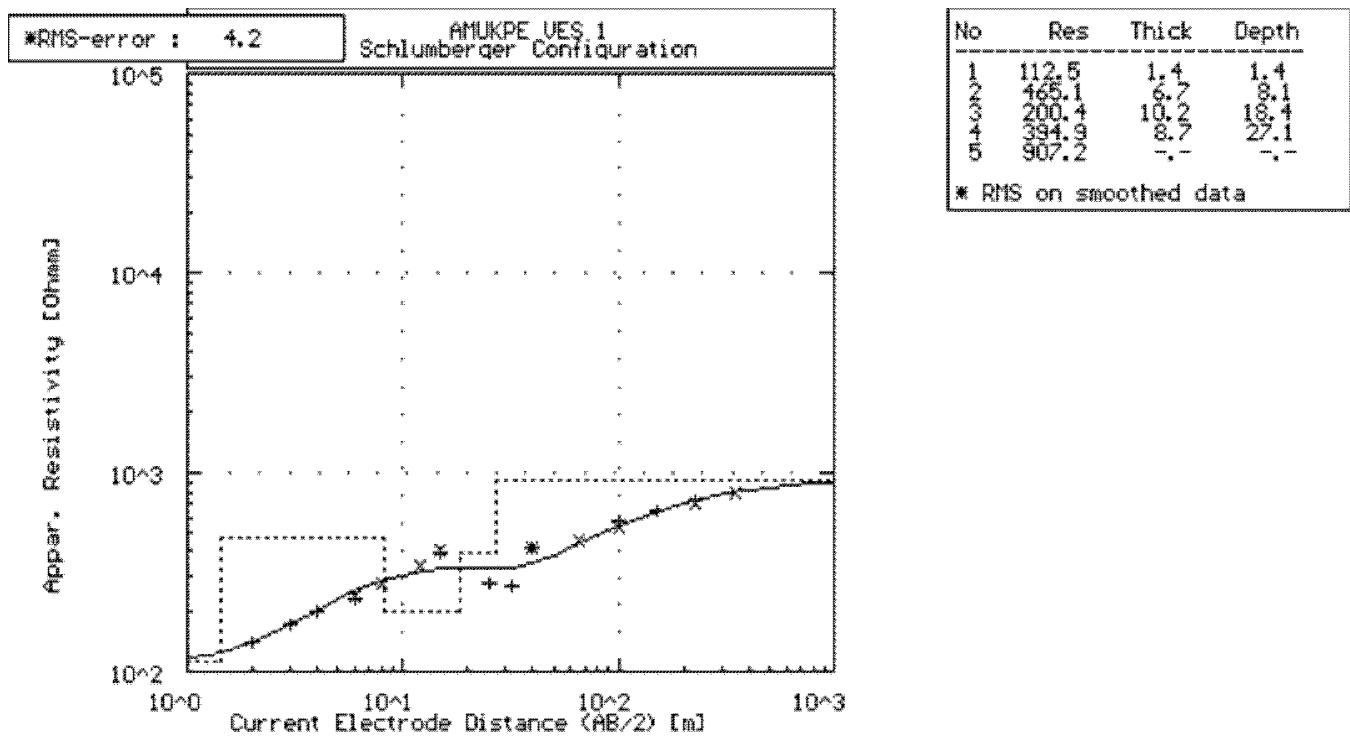

Figure4a: Typical Sounding Curve for Amukpe Hydrogeophysical Investigation (VES 1).

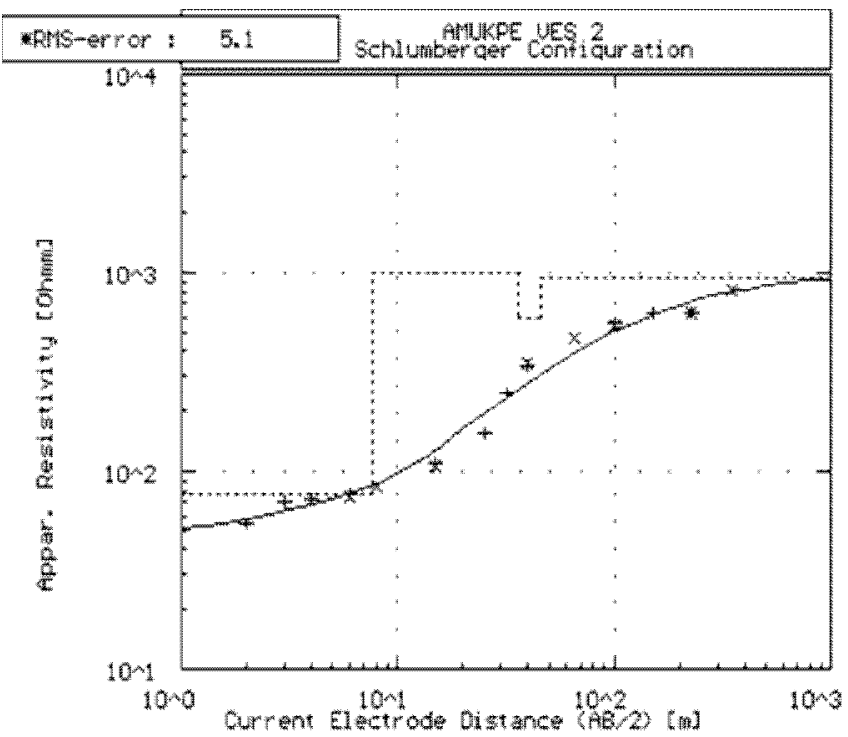

\begin{tabular}{|c|c|c|c|}
\hline No & $\mathrm{R}$ os & This & Depth \\
\hline $\begin{array}{l}\frac{1}{2} \\
\frac{3}{5} \\
\frac{4}{5}\end{array}$ & $\begin{array}{r}49.3 \\
76.6 \\
100.0 \\
547.1\end{array}$ & $\begin{array}{r}1.1 \\
6.2 \\
28.2 \\
3.7 \\
*\end{array}$ & $\begin{array}{r}1.0 \\
35.6 \\
35 * 6 \\
* . *\end{array}$ \\
\hline
\end{tabular}

Figure4b: Typical Sounding Curve for Amukpe Hydrogeophysical Investigation (VES 2). 
Nigerian Journal of Basic and Applied Science (March, 2013), 21(1): 11-19

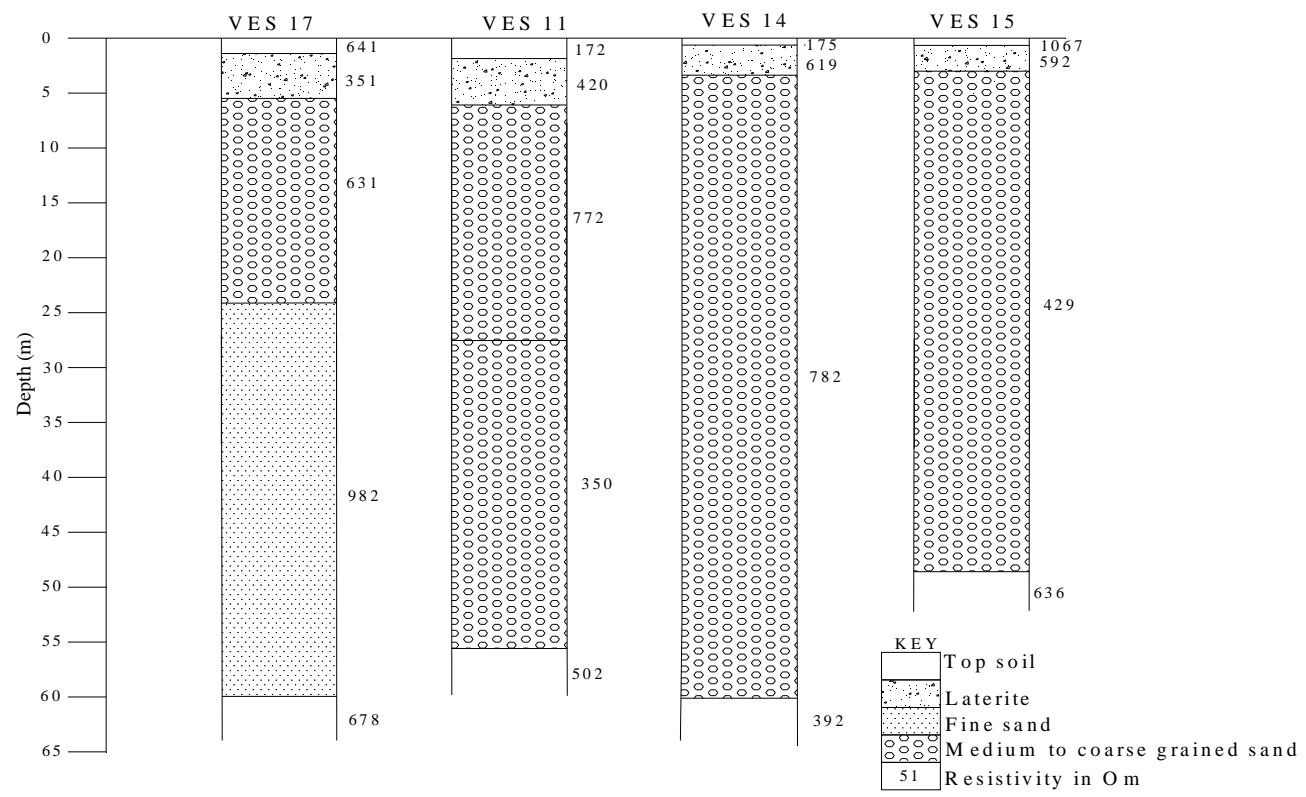

Figure 5: Geoelectric section of Amukpe

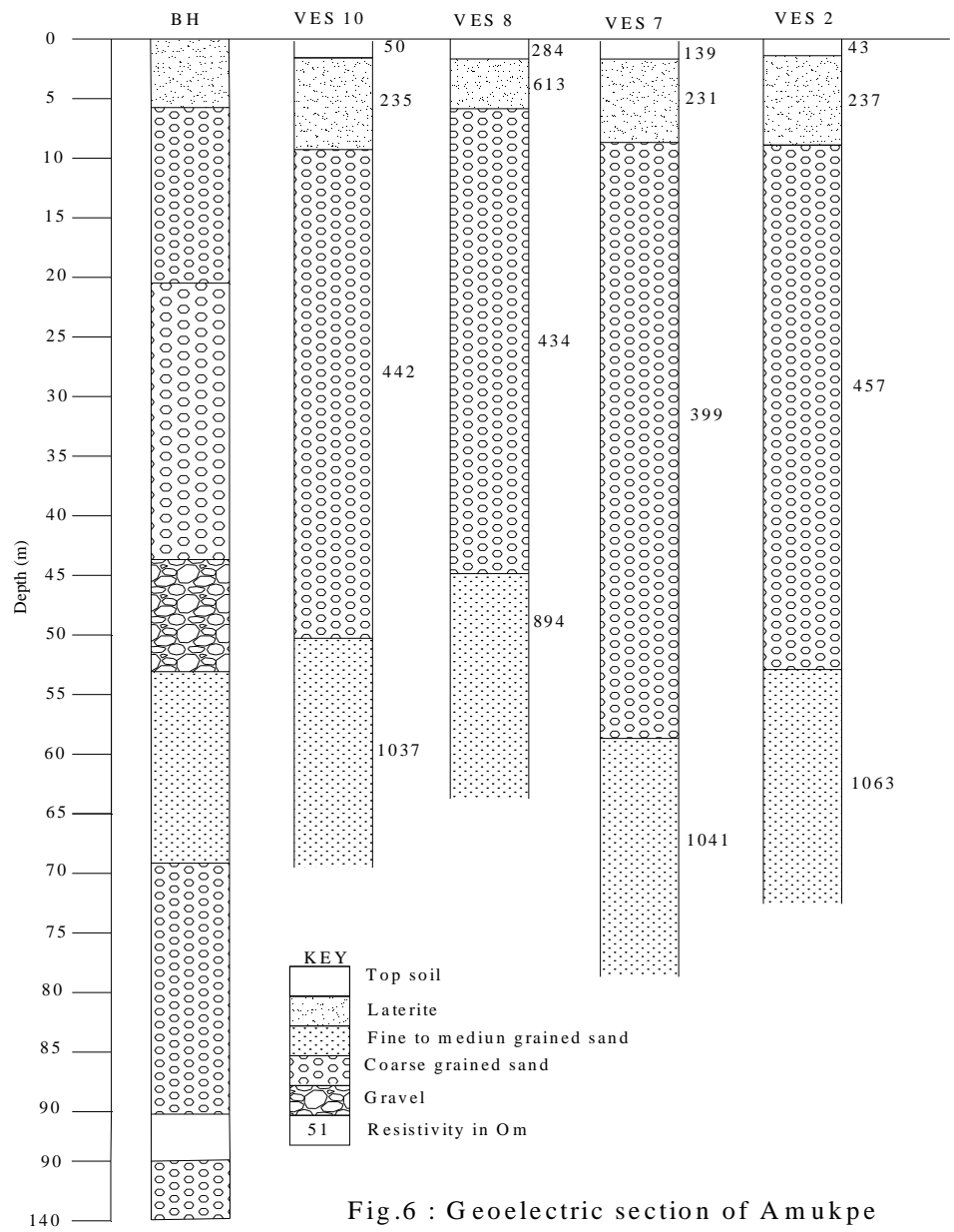




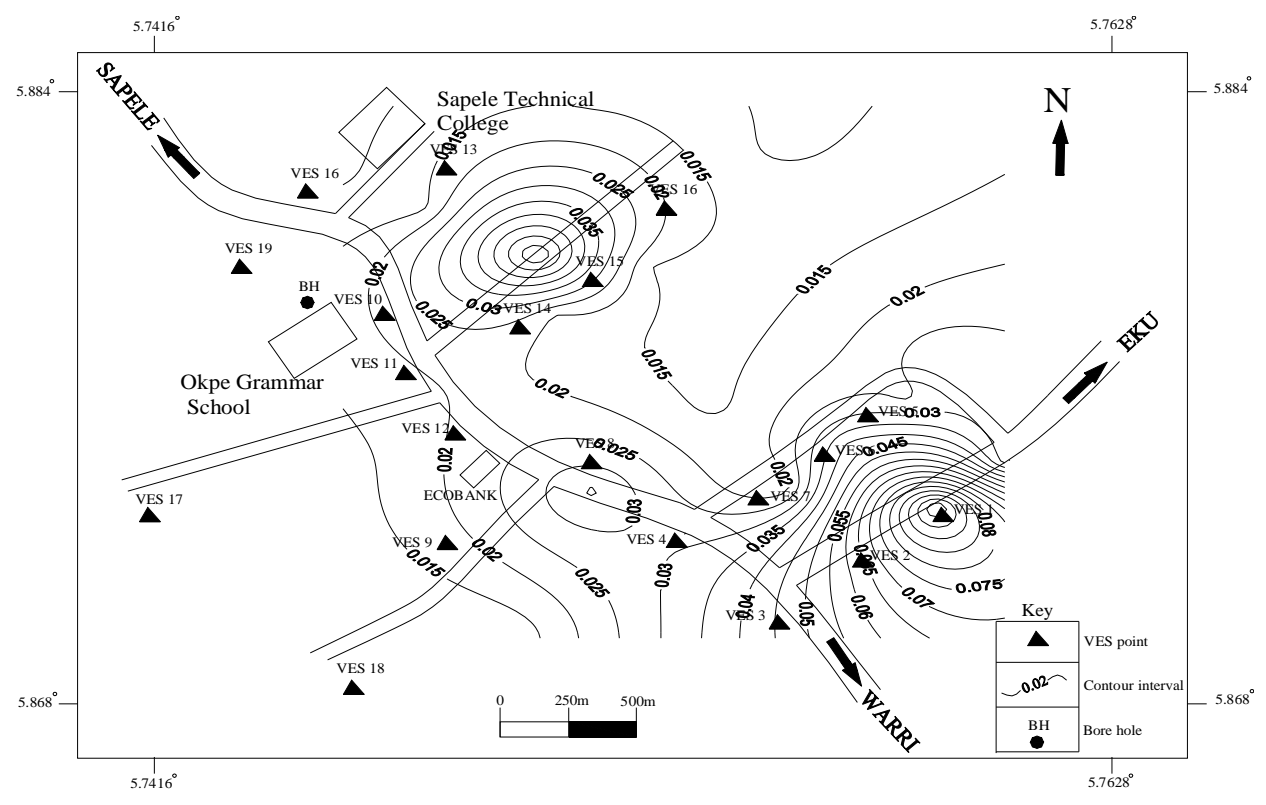

Figure 7: Protective capacity map of Amukpe

\section{Geoelectric Section}

Three distinct geoelectric layers namely the topsoil, laterite/clayey sand and sand (medium to coarse grained) were delineated from the geoelectric sections. The topsoil has resistivity values ranging from 43 to $1067 \Omega \mathrm{m}$ and thickness varying from 0.8 to $1.6 \mathrm{~m}$. The second geoelectric layer is composed of clayey sand and laterite with resistivity values ranging from 77 to $644 \Omega \mathrm{m}$ and thickness varying from 3.8 to $6.7 \mathrm{~m}$. The third geoelectric layer represents the aquiferous unit with resistivity values ranging from 200 to $1067 \Omega \mathrm{m}$ diagnostic of sand (fine to coarse grained). Though the electrode current terminated within this layer, inference from VES 7 and 13 (table 1) shows a possible thickness of more than $90 \mathrm{~m}$. The interpreted geoelectric data correlates well with the lithologic log of a borehole drilled close to VES 1 and 3 at the Okpe Grammar School to a depth of 138m (FMWR,1983).

\section{Longitudinal Unit Conductance Map}

The longitudinal conductance map (Figure 7) shows that Amukpe is not protected since the protective capacity rating is poor $(<0.1)$ in all the parts of the study area. The low value of the protective capacity is as a result of the absence significant amount of clay as an overburden impermeable material in the study area thereby enhancing the percolation of contaminants into the aquifer. The aquifer in Amukpe community is therefore prone to contamination in the event of hydrocarbon pollution.

\section{CONCLUSION}

This paper describes the determination of the overburden protective capacity using the electrical resistivity survey. Nineteen Schlumberger vertical electrical soundings were carried out in Amukpe area of Delta State with maximum electrode separation of $1000 \mathrm{~m}$. The VES data were presented as VES curves interpreted quantitatively by computer iteration using the Resist Software to obtain the first order geoelectric parameters. The results of the geoelectric investigation have revealed three geoelectric layers namely the topsoil, laterite/clayey sand and sand (medium to coarse grained) that are in agreement with the actual lithology encountered from the borehole logs. These first order geoelectric parameters were utilized in deriving the longitudinal unit conductance (S). The overburden protective capacity in an area was evaluated using the total longitudinal unit conductance values. The generated longitudinal conductance maps showed poor protective capacity $(<0.1 \mathrm{mhos})$ in all parts of the study area. The study area is not protected hence the aquifer in this oil producing community is prone to contamination by hydrocarbon in the event of pollution. Awareness should be created by encouraging the inhabitants to drink potable water from deep boreholes and discourage them from drinking water from hand dug wells which can be easily polluted. Groundwater monitoring wells should be provided in the 
community and regular water quality analysis conducted.

\section{REFERENCES}

Akpoborie, I.A., Ekakitie, O.A. and Adaikpoh, E.O. (2000). The Quality of Groundwater from Dug wells in parts of the Western Niger Delta. Knowledge Review, 2(5): 72-79.

Asseez, O.L. (1989). Review of the Stratigraphy, Sedimentation and Structure of the Niger Delta. Edited by Kogbe, Rock View (Nig.) Ltd. Jos. pp. 311-324.

Atakpo, E.A. and Ayolabi, E.A. (2009). Evaluation of aquifer vulnerability and the protective capacity in some oil producing communities of western Niger Delta. Environmentalist, 29:310-317.

Ayolabi, E.A. (2005). Geoelectric evaluation of Olushosun Landfill Site Southwest Nigeria and its Implication on Groundwater. Journ. Geological Society of India, 66: 318-322.

Henriet, J.P. (1976). Direct application of the Dar Zarrouk parameters in groundwater surveys. Geophysics Prospective, 24: 344-353.

Maillet, R. (1947). The fundamental equations of Electrical Prospecting. Geophysics, 12: 527556.
Oladapo, M.I, Mohammed, M.Z, Adeoye, O.O. and Adetola, B.A. (2004). Geoelectrical investigation of the Ondo State Housing Corporation Estate, ljapo Akure, Southwestern Nigeria. Journal of Mining and Geology, 40(1): 41-48.

Olorunfemi, M.O, Ojo, J.S. and Oladapo, M.I. (1998). Geological, hydrogeological and geophysical investigation of exposed 20" Escravos Lagos Pipeline. Technical report.

Oomkens, E. (1974). Lithofacies relations in the late quaternary Niger Delta Complex. AAPG Bulletin, 24: $195-222$

Ozumba, C.I, Ozumba, M.B. and Obobaifo, C.E..(1999). Striking a balance between oil exploration and protecting the environment. NAPE Bulletin 14(2): 130-135.

Short, K.C. and Stauble, A.J. (1967). Outline of Geology of Niger Delta: AAPG Bulletin, 51: 761779 .

Surfer (2002). Contouring and 3D surface mapping for scientists and engineers. Golden software Incorporation, Colorado, USA.

Vander Velpen. B.P.A. (2004). Win RESIST Version 1.0. M. Sc Research Project. ITC, Deft, Netherlands. 